\title{
KEPEMILIKAN INSTITUSIONAL, KEPEMILIKAN MANAJERIAL, DAN UKURAN PERUSAHAAN TERHADAP KEBIJAKAN DIVIDEN
}

\author{
Dewi Rahayu \\ dedewi198@gmail.com \\ Ellen Rusliati \\ Fakultas Ekonomi dan Bisnis, Universitas Pasundan Bandung
}

diterima: 22/12/2017; direvisi: 27/2/2019; diterbitkan: 30/4/2019

\begin{abstract}
The aim of this study to determine the effect of institutional ownership, managerial ownership, firm size, to dividend policy simultaneously and partially. The population of this study are manufacturing companies in the consumer goods industry sector listed in Indonesia Stock Exchange of 2008-2017, the sample amounted 6 companies. The method used in this study are descriptive and verificative using panel data regression analysis. The results showed that the simultaneously institutional ownership, managerial ownership and firm size has significant effect on dividend policy with contribution of effect equal to $39.62 \%$. The partially, institutional ownership has a significant positive effect on dividend policy, managerial ownership has a significant negative effect on dividend policy, firm size has a significant positive effect on dividend policy. The effect contribution dominant of independent variables is institutional ownership equal to $29.2 \%$, managerial ownership equal to $10 \%$ and firm size equal to $0.4 \%$.
\end{abstract}

Keywords: institutional ownership; managerial ownership; firm size; dividend policy; dividend payout ratio

\begin{abstract}
Abstrak
Penelitian ini bertujuan untuk mengetahui pengaruh kepemilikan institusional, kepemilikan manajerial, ukuran perusahaan, terhadap kebijakan dividend payout ratio secara simultan dan parsial. Populasi pada penelitian ini adalah perusahaan manufaktur sektor industri barang konsumsi periode 2008-2017 dengan sampel sebanyak 6 perusahaan. Penelitian ini menggunakan metode deskriptif dan verifikatif dengan regresi data panel. Hasil penelitian menunjukkan bahwa kepemilikan institusional, kepemilikan manajerial dan ukuran perusahaan secara simultan berpengaruh signifikan terhadap kebijakan dividen dengan kontribusi pengaruh sebesar 39,62\%. Secara parsial kepemilikan institusional berpengaruh positif signifikan terhadap kebijakan dividen, kepemilikan manajerial berpengaruh negatif signifikan terhadap kebijakan dividen, ukuran perusahaan berpengaruh positif signifikan terhadap kebijakan dividen. Kontribusi pengaruh variabel independen yang dominan adalah kepemilikan institusional sebesar 29,2\%, kontribusi pengaruh kepemilikan manajerial sebesar $10 \%$, dan ukuran perusahaan sebesar $0,4 \%$.
\end{abstract}

Kata Kunci: kepemilikan institusional; kepemilikan manajerial; ukuran perusahaan; kebijakan dividen; dividend payout ratio 


\section{PENDAHULUAN}

Dividen sebagai keuntungan yang didistribusikan oleh perusahaan terhadap pemegang saham merupakan tujuan utama suatu bisnis yaitu memakmurkan pemegang saham. Dividen yang dibayarkan perusahaan berasal dari sebagian laba bersih setiap tahun buku. Besaran dividen yang didistribusikan perusahaan didasarkan pada kebijakan dividen yang ditentukan dalam Rapat Umum Pemegang Saham (RUPS). Kebijakan dividen adalah keputusan apakah laba yang diperoleh perusahaan akan dibagikan kepada pemegang saham sebagai dividen atau akan ditahan dalam bentuk laba ditahan guna pembiayaan investasi di masa yang akan datang (Sartono, 2011:28). Dividend payout ratio (rasio pembayaran dviden) ini digunakan karena dapat menunjukkan besaran atau presentase dividen yang dibagikan dari laba bersih setelah pajak serta dapat menunjukkan besaran laba ditahan yang akan digunakan untuk kebutuhan investasi.

Penelitian ini dilakukan pada perusahaan manufaktur sektor industri barang konsumsi yang terdaftar di Bursa Efek Indonesia. Sektor industri barang konsumsi menjadi sektor yang masih akan tumbuh meski menghadapi tekanan terhadap kenaikan harga bahan baku akibat pelemahan rupiah, tingginya inflasi, dan kenaikan suku bunga (m.katadata.co.id). Sektor industri barang konsumsi mengalami pertumbuhan dan perkembangan yang cukup pesat dan cepat . hal ini ditopang dari tingginya tingkat konsumsi masyarakat, utamanya sektor industri barang konsumsi yang menawarkan kebutuhan mendasar konsumen (ww. neraca.co.id). Pertumbuhan sektor industri barang konsumsi Pertumbuhan sektor industri barang konsumsi di Indonesia ternyata tidak diimbangi oleh peningkatan nilai dividen. Hal ini terbukti dengan adanya perusahaan yang tidak membagikan dividen secara rutin selama lima tahun selama periode penelitian, dari 42 emiten yang berada di sektor industri barang konsumsi hanya 13 yang rutin membagikan dividen secara rutin selama 10 tahun (periode penelitian 2008-2017). Hal ini dapat disebabkan karena beberapa emiten lebih memilih menahan labanya untuk digunakan untuk investasi di masa yang akan datang dibandingkan melakukan pembagian dividen kepada pemegang saham.

Kebijakan dividen dapat dipengaruhi oleh kepemilikan institusional, kepemilikan manajerial, dan ukuran perusahaan. Masalah keagenan terjadi karena pemegang saham dengan para manajer memiliki keinginan dan kepentingannya sendiri. Pembayaran dividen dilakukan untuk mengurangi masalah keagenan antara manajer dan pemegang saham (Baker, 2015). Kepemilikan institusional adalah pemegang saham yang dapat mengurangi masalah keagenan di dalam perusahaan, karena institusional investor akan lebih berhati-hati dan teliti dalam mengendalikan pengambilan keputusan pihak manajemen yang tidak sejalan dengan kepentingan pemegang saham (Dhuhri dan Diantimala, 2018). Kepemilikan institusional menyebabkan pengawasan terhadap manajemen perusahaan menjadi lebih tinggi.

Masalah keagenan juga dapat dikurangi, agar pihak manajemen dapat bertindak sejalan dengan kepentingan pemegang saham dengan cara meningkatkan kepemilikan manajerial. Memberikan kesempatan manajer untuk terlibat dalam kepemilikan saham dengan tujuan menyetarakan kepentingan dengan pemegang saham. Keterlibatan manajemen dalam kepemilikan saham akan memotivasi untuk meningkatkan kinerja dalam pengelolaan perusahaan dan mampu bertindak secara hati-hati dalam pengambilan keputusan.

Life cycle theory menunjukkan bahwa tahap siklus hidup dari suatu perusahaan mempengaruhi kebijakan dividen (Arko, et. al., 2014). Life cycle theory dengan menggunakan proksi ukuran perusahaan (Arko, et.al. 2014; Sukkaew, 2015) menyatakan bahwa perusahaan yang besar cenderung untuk lebih dewasa dan mempunyai akses yang lebih mudah dalam pasar modal. Hal tersebut akan mengurangi ketergantungan mereka pada pendanaan internal, sehingga perusahaan akan memberikan pembayaran dividen yang tinggi.

Perumusan masalah pada penelitian ini adalah sebagai berikut: (1) Bagaimana kondisi kepemilikan institusional, kepemilikan manajerial, ukuran perusahaan, dan kebijakan dividen, (2) Seberapa besar pengaruh kepemilikan institusional, kepemilikan manajerial dan ukuran perusahaan secara simultan terhadap kebijakan dividen, (3) Seberapa besar pengaruh kepemilikan institusional terhadap kebijakan dividen, (4) Seberapa besarpengaruh kepemilikan manajerial terhadap kebijakan dividen, (5) Seberapa besar pengaruh ukuran perusahaan terhadap kebijakan dividen pada perusahaan manufaktur sektor industri barang konsumsi yang terdaftar di Bursa Efek Indonesia (BEI) periode 2008-2017.

Kepemilikan institusional diharapkan mampu melaksanakan fungsi monitoring yang efektif terhadap manajemen perusahaan dalam pengambilan keputusan. Tingkat saham institusional yang tinggi akan menghasilkan upaya-upaya pengawasan yang lebih intensif sehingga dapat membatasi perilaku opportunitis manajer, yaitu manajer melaporkan laba secara oportunitis untuk memaksimumkan kepentingan pribadinya (Scott, 2000 dalam Dewi, 2008).

Pujiati (2015) menyatakan bahwa kepemilikan institusional berpengaruh positif terhadap kebijakan dividen. Semakin besar kepemilikan saham institusional maka kebijakan dividen yang ditetapkan semakin besar. Hasil penilitian ini sama dengan hasil penelitian yang dilakukan oleh Helmina dan Hidayat tahun 2017 menyatakan kepemilikan institusional berpengaruh positif terhadap kebijakan dividen bahwa semakin tinggi kepemilikan institusional maka semakin tinggi dividend payout ratio yang akan dibagikan. Penyataan di atas berbanding terbalik dengan Dhuhri dan Diantimala 
(2018) yang menyatakan kepemilikan institusional berpengaruh negatif. Kepemilkan institusional yang meningkat akan menurunkan dividend payout ratio.

Agency cost theory merumuskan bahwa salah satu cara untuk meminimalkan biaya agensi yang terjadi karena konflik kepentingan antara pemegang saham dan manajer adalah melalui kepemilikan saham manajemen. Sehingga, manajer yang berperan sebagai pemegang saham memiliki kepentingan terhadap dividen yang dibagikan perusahaan.

Hasil penelitian Pujiati (2015) menyatakan bahwa kepemilikan manajerial, berpengaruh positif terhadap kebijakan dividen. Kepemilikan manajerial yang tinggi akan menyebabkan aset yang dimiliki tidak terdiversifikasi secara optimal sehingga manajerial menginginkan return atas opportunity cost yaitu dengan pembagian dividen yang semakin besar. Sebaliknya perusahaan yang memiliki kepemilikan manajerial yang rendah menunjukkan diversifikasi yang optimal sehingga cenderung lebih menyukai retained earning dan kemudian akan membayar dividen dalam jumlah yang rendah.

Perusahaan dengan ukuran yang lebih besar memiliki arus kas operasi yang lebih stanil sehingga peluangnya membagikan dividen lebih besar. Berdasarkan teori free cash flow, perusahaan yang berukuran lebih besar memiliki arus kas yang lebih tinggi sehingga dividen yang dibayarkan pun lebih tinggi juga.

Penelitian yang telah dilakukan oleh Dewi (2008) menjelaskan pengaruh atau hubungan yang positif dengan dividend payout ratio hal ini dapat menjelaskan bahwa perusahaan yang besar akan cenderung memiliki rasio pembayaran dividen yang tinggi dibandingkan dengan perusahaan yang kecil yang akan cenderung memiliki rasio pembayran dividen yang rendah. Paradigma penelitian ditunjukkan pada Gambar 1.

Berdasarkan kerangka pemikiran dan rumusan masalah, maka hipotesis dalam penelitian ini adalah : (1) Hipotesis Simultan: Terdapat pengaruh kepemilikan institusional,kepemilikan manajerial dan ukuran perusahaan secara simultan terhadap kebijakan dividen, (2) Hipotesis Parsial : (a) Terdapat pengaruh kepemilikan institusional terhadap kebijakan dividen, (b) Terdapat pengaruh kepemilikan manajerial terhadap kebijakan dividen, (c) Terdapat pengaruh ukuran perusahaan terhadap kebijakan dividen.

\section{METODE}

Penelitian ini menggunakan metode deskriptif dan verifikatif. Populasi adalah perusahaan manufaktur sektor industri barang konsumsi yang terdaftar di Bursa Efek Indonesia selama periode 2008-2017. Operasionalisasi variabel ditunjukkan pada Tabel 1. Teknik pengambilan sampel adalah purposive sampling, dengan kriteria perusahaan yang terdaftar di BEI, mempublikasikan laporan keuangan, membagikan dividen, serta memiliki kepemilikan manajerial selama periode penelitian. Sampel berjumlah 6 perusahaan dengan jumlah observasi sebanyak 60 data.

Teknik pengumpulan data yang dilakukan adalah studi kepustakaan, observasi tidak langsung serta dokumentasi. Analisis deskriptif menggunakan nilai rata-rata, nilai maksimum, dan minimum. Analisis verifikatif menggunakan analisis data panel dengan Microsoft Excel, SPSS, dan Eviews 9. Data diperoleh dari laporan keuangan perusahaan manufaktur sektor industri barang konsumsi yang terdaftar di Bursa Efek Indonesia periode 2008-2017, dengan mengakses www. idx.co.id dan www.sahamoke.com.

\section{HASIL}

Gambar 1 menunjukkan kondisi kepemilikan institusional pada perusahaan manufaktur sektor industri barang konsumsi yang terdaftar di Bursa Efek Indonesia periode 2008-2017 adalah berfluktuasi, menurun kemudian cenderung meningkat. Rata-rata kepemilikan institusional yang cenderung meningkat karena semakin banyak jumlah saham yang dimiliki oleh pihak institusi dari jumlah saham yang beredar. Kondisi meningkatnya kepemilikan saham oleh institusi dapat berdampak baik bagi perusahaan, karena dapat berperan sebagai kontrol atas kinerja manajemen selaku pihak yang menjalankan operasional perusahaan.

Gambar 2 menunjukkan kondisi kepemilikan manajerial pada perusahaan manufaktur sektor industri barang konsumsi yang terdaftar di Bursa Efek Indonesia periode 2008-2017 adalah berfluktuasi, yaitu naik dan kemudian menurun pada 4 tahun terakhir. Kepemilikan manajerial yang menurun dapat berdampak tidak baik bagi perusahaan karena dapat menimbulkan masalah keagenan yaitu masalah yang terjadi karena memiliki perbedaan kepentingan pihak manajemen dan pemilik perusahaan. Kepemilikan manajerial memberikan kesempatan bagi manajemen untuk terlibat dalam kepemilikan saham dan dapat mensetarakan dengan pemegang saham. Pihak manajemen yang memiliki saham manajerial diharapkan mampu memberikan kinerja yang baik bagi perusahaan, tidak mengutamakan kepentingan masing-masing dan berusaha memakmurkan pemegang saham.

Gambar 3 menunjukkan ukuran perusahaan manufaktur sektor industri barang konsumsi yang terdaftar di Bursa Efek Indonesia periode 2008-2017 adalah cenderung meningkat. Ukuran perusahaan yang besar menunjukkan bahwa perusahaan tersebut memiliki total aset yang lebih besar. Perusahaan yang memiliki skala yang besar cenderung lebih mudah mendapatkan modal dari pihak ekternal karena memiliki akses yang mudah di pasar modal.

Gambar 4 menunjukkan kondisi kebijakan dividen yang tercermin pada dividend payout ratio pada perusahaan manufaktur sektor industri barang konsumsi yang terdaftar di Bursa Efek Indonesia periode 2008- 
2017 adalah berfluktuatif, naik kemudian menurun. Dividend payout ratio yang tinggi menunjukkan bahwa perusahaan tersebut lebih banyak menggunakan laba bersih sebagai dividen dari pada sebagai laba ditahan. Dividend payout ratio yang rendah menunjukkan bahwa perusahaan tersebut lebih banyak menggunakan laba bersih sebagai laba ditahan dari pada sebagai dividen. Dividend payout ratio yang menurun dapat berdampak tidak baik kepada perusahaan dapat memunculkan ketidakyakinan pemegang saham untuk menanamkan modalnya di perusahaan tersebut.

Hasil regresi yang dapat dilihat pada Tabel 4, dengan bentuk persamaan regresi data panel dengan model common effect adalah sebagai berikut:

$$
\begin{aligned}
& Y=51,13539+1,038502 X_{1}-39,01389 X_{2}+8,590680 \\
& \mathrm{X}_{3}+\varepsilon
\end{aligned}
$$

Dimana :

$\mathrm{Y}=$ Kebijakan Dividen

$\mathrm{X}_{1}=$ Kepemilikan Institusional

$\mathrm{X}_{2}=$ Kepemilikan Manajerial

$\mathrm{X}_{3}=$ Ukuran Perusahaan

Pengujian hipotesis common effect dapat dilihat pada Tabel 5, bahwa kepemilikan institusional, kepemilikan manajerial dan ukuran perusahaan secara simultan berpengaruh signifikan terhadap kebijakan dividen pada perusahaan manufaktur sektor industri barang konsumsi periode 2008-2017.

Berdasarkan Tabel 6 dapat diputuskan bahwa terdapat pengaruh signifikan kepemilikan institusional, dan ukuran perusahaan berpengaruh positif terhadap kebijakan dividen, sedangkan kepemilikan manajerial berpengaruh negatif pada perusahaan manufaktur sektor industri barang konsumsi yang terdaftar di Bursa Efek Indonesia periode 2008-2017.

Nilai R-Squared pada Tabel 7 adalah sebesar 0,3962 atau $39,62 \%$. Nilai tersebut menunjukkan bahwa kontribusi pengaruh variabel independen yaitu kepemilikan institusional, kepemilikan manajerial dan ukuran perusahaan secara simultan atau bersamasama memberikan pengaruh sebesar $39,62 \%$ terhadap kebijakan dividen pada perusahaan manufaktur sektor industri barang konsumsi yang terdaftar di Bursa Efek Indonesia periode 2008-2017, sedangkansisanya yaitu sebesar 60,38\% dipengaruhi oleh variabel lain yang tidak diamati dalam penelitian ini.

Berdasarkan Tabel 8 dapat dilihat bahwa perhitungan koefisien determinasi parsial adalah (1) Kontribusi pengaruh kepemilikan institusional terhadap kebijakan dividen sebesar 0,601x 0,484x 100\% $=0,292 \rightarrow 29,2 \%$, (2) Kontribusi pengaruh kepemilikan manajerial terhadap kebijakan dividen $=-0,635 \mathrm{x}-0,158 \mathrm{x} \quad 100 \%$ $=0,100 \rightarrow 10 \%$, (3) Kontribusi pengaruh ukuran perusahaan terhadap kebijakan dividen $=0,715 \times 0,006 x$ $100 \%=0,004 \rightarrow 0,4 \%$.

\section{PEMBAHASAN}

Kepemilikan institusional berpengaruh positif terhadap kebijakan dividen. Semakin tinggi saham yang dimiliki oleh pihak institusi dalam perusahaan, semakin tinggi kebijakan dividen. Kepemilikan institusional sebagai pemegang saham mayoritas dapat berperan sebagai kontrol dan pengawas terhadap kinerja manajemen perusahaan. Scott (2000) dalam Firmanda, et.al. (2015) menjelaskan bahwa kepemilikan saham institusional yang tinggi akan menghasilkan upayaupaya pengawasan yang lebih intensif sehingga dapat membatasi perilaku manajer.

Hasil penelitian ini sejalan dengan penelitian yang telah dilakukan Pujiati (2015), Helmina dan Hidayat (2017), serta Thanatawee (2013), Shaheen and Ullah (2018), sedangkan hasil penelitian Dhuhri dan Diantimala (2018) menyatakan bahwa kepemilikan institusional berpengaruh negatif terhadap kebijakan dividen. Kepemilikan institusional sebagai pemegang saham mayoritas yang mempunyai peran sebagai kontrol untuk mengurangi masalah keagenan, sesuatu yang lebih disukai oleh investor institusi adalah alternatif yang dapat menyediakan keuntungan lebih baik, dalam konteks ini alternatif tersebut adalah pajak yang rendah. Selain itu pada umumnya kepemilikan institusional mempunyai pajak yang tinggi, oleh karena itu kepemilikan institusional cenderung tidak menyukai dividend payout ratio yang tinggi, dan lebih menyukai capital gain karena pajaknya rendah.

Kepemilikan manajerial berpengaruh negatif terhadap kebijakan dividen. Semakin rendahkepemilikan manajerialsemakin tinggi kebijakan dividen, semakin tinggi kepemilikan manajerial semakin rendah kebijakan dividen. Perusahaan yang memiliki kepemilikan manajerial yang rendah cenderung memberikan dividen yang tinggi hal ini dilakukan untuk tetap mempertahankan kepercayaan pemegang saham terhadap pertumbuhan perusahaan. perusahaan yang memiliki kepemilikan manajerial yang tinggi cenderung membagikan dividen dalam jumlah yang rendah karena perusahaan cenderung mengalokasikan laba bersih sebagai laba ditahan guna pembiayaan investasi di masa depan hal inimenunjukkan bahwa perusahaan beranggapan bahwa investasi menggunakan modal internal lebih efisien dibanding menggunakan dana dari pihak ekternal.

Hasil penelitian ini sejalan dengan penelitian yang telah dilakukan oleh Ismiati (2017) dan Dhuhri dan Diantimala (2018), Shaheen and Ullah (2018), sedangkan Pujiati (2015), Silaban dan Pengestuti (2017) menyatakan bahwa kepemilikan manajerial berpengaruh positif terhadap kebijakan dividen. Perusahaan yang memiliki kepemilikan manajerial yang rendah menunjukkan diversifikasi yang optimal sehingga cenderung lebih menyukai retained earning dan kemudian akan membayar dividen dalam jumlah yang rendah. 
Ukuran perusahaan berpengaruh positif terhadap kebijakan dividen. Ukuran perusahaan mencerminkan skala yang dimiliki dengan menilai total aset. Ukuran perusahaan yang besar mencerminkan bahwa perusahaan mampu mengelola dan memanfaaatkan asetnya untuk kegiatan operasionya. Ukuran perusahaan yang besar memungkinkan perusahaan memperoleh laba bersih yang besar sehingga memberikan dividen yang besar. Dewi (2008) mengatakan bahwa perusahaan yang kecil cenderung akan mengalokasikan laba bersih ke laba ditahan untuk menambah aset perusahaan sehingga cenderung membagikan dividen rendah. Hasil penelitian ini sejalan dengan penelitian yang telah dilakukan oleh Dewi (2008), Khoiro (2016), Sinabutar dan Nugroho (2015), Ahmad dan Wardani (2014), Silaban dan Pengestuti (2017) dan Dhuhri dan Diantimala (2018).

\section{KESIMPULAN}

Kepemilikan institusional pada perusahaan manufaktur sektor industri barang konsumsi yang terdaftar di Bursa Efek Indonesia periode 2008-2017 mengalami fluktuasi, menurun tahun 2010 sampai dengan 2012 dan selanjutnya cenderung meningkat. Kepemilikan manajerial cenderung menurun. Ukuran perusahaan meningkat. Kebijakan dividen cenderung menurun. Besarnya pengaruh kepemilikan institusional, kepemilikan manajerial dan ukuran perusahaan sebesar 39,62\% terhadap kebijakan dividen. Besarnya pengaruh kepemilikan institusional terhadap kebijakan dividen adalah sebesar 29,2\%. kepemilikan manajerial memberikan kontribusi pengaruh sebesar $10 \%$, dan ukuran perusahaan adalah sebesar $0,4 \%$.

\section{DAFTAR PUSTAKA}

Ahmad, Gatot N. dan Vina K. Wardani. 2014. The Effect Of Fundamental Factor To Dividend Policy: Evidence In Indonesia Stock Exchange The Period Of 2006-2009. International Journal of Business and Commerce, Vol. 4, No. 2, hal. 14-25.

Arko, A. C., Abor, J., Adjasi, C. K. D., \& Amidu, M. 2014. What Influence Dividend Decisions of Firms in SubSaharan African?.Journal of Accounting in Emerging Economies, Vol 4(1), pp 57-78

Baker, H. Kent. 2015. Corporate Dividend Policy Revisited. Managerial Finance, Vol.4, No.2, pp 126-144.

Dewi, Sisca Christianty. 2008. Pengaruh Kepemilikan Manajerial, Kepemilikan Institusional, Kebijakan Hutang, Profitabilitas dan Ukuran Perusahaan Terhadap Kebijakan Dividen. Jurnal Bisnis dan Akuntansi, Vol. 10, No. 1, hal. 47-48.

Dhuhri, Rani dan Yossi Diantimala. 2018. The Influence Of Institutional Ownership, Individual Ownership, and Managerial Ownership Toward Dividend
Payout Ratio at Non-Financial Companies Registered In Indonesia Stock Exchange in 20122106. International Journal Of Social Science and Economic Research, Vol. 3 (3), pp 786-801.

Firmanda. Ridho; Kharis Raharjo; dan Abrar Oemar. 2015. Pengaruh Kepemilikan Manajerial, Kepemilikan Institusional; Kebijakan Hutang, Profitabilitas, Ukuran Perusahaan, dan Cash Position Terhadap Kebijakan Dividen. Jurnal Ilmiah Mahasiswa S1 Akuntansi Universitas Pandanaran. Februari. Vol. 1 No. 1.

Helmina, Monica dan Raudhatul Hidayat. 2017. Pengaruh Institutional Ownership, Collateralizable Assets, Debt To Total Assets, Firm Size Terhadap Dividend Payout Ratio Pada Perusahaan Terdaftar di Bursa Efek Indonesia Periode 2013-2014. Jurnal Ilmiah Ekonomi Bisnis, Vol. 3, No. 1, hal. 24 - 32.

Ismiati, Putri Indah. 2017. Pengaruh Kepemilikan Manajerial, Kepemilikan Institusional, dan Kebijakan Hutang Terhadap Kebijakan Dividen Pada Perusahaan Food and Beverage Terdaftar di Bursa Efek Indonesia Periode 2012-2015 . Jurnal Ilmu dan Riset Manajemen, Vol. 6, No. 3, hal. 1-19. Khoiro, Evada El Ummah; Suhadak Suhadak; dan Siti Ragil Handayani. 2016. The Influence of Capital Structure and Firm Size on Profitability and Dividend Policy. Profit; Jurnal Administrasi Bisnis. Universitas Brawijaya. Vol. 10. No. 2. pp 1-10.

Pujiati. 2015. Faktor-Faktor yang Mempengaruhi Kebijakan Dividen Sektor Industri Barang Konsumsi Terdaftar di Bursa Efek Indonesia Periode 20082013 . Jurnal Nominal, Vol. 4, No. 1, hal. 49-66.

Sartono, Agus. 2011. Manajemen Keuangan. Teori dan Aplikasi. BPFE. Yogyakarta.

Shaheen, Riffat and Sabeeh Ullah. 2018. Effect of Institutional and Insider Ownership on Dividend Policy: Evidence from Pakistan. Journal of Business and Tourism. Volume 04 Number 02. July-December.

Silaban, Christy N. dan Irene R.D. Pengestuti, 2017. Analisis Faktor-Faktor yang Mempengaruhi Kebijakan Deviden dengan Firm Size sebagai Variabel Kontrol. Diponegoro Journal Of Management, Vol.. 6, No. 3, hal. 1-15.

Sinabutar, Alexander dan Anggoro B. Nugroho. 2015. Dividend Payout Ratio in Indonesian Consumer Goods Industry: Panel Analysis And Determinant Factors in 2004-2013. Journal of Business and Management, Vol. 4, No. 4, hal. 453-464.

Thanatawee, Yording. 2013. Ownership Structure and Dividend Policy: Evidence From Thailand. International Journal Of Economic And Finance, Vol. 5, No.1, pp 121-132.

www.idx.co.id

www.sahamoke.com 
Tabel 1. Operasionalisasi Variabel

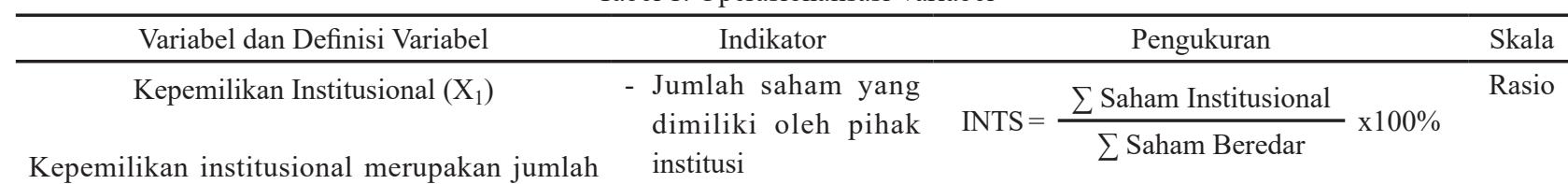

kepemilikan oleh investor institusi di luar - Jumlah saham yang

perusahaan.

beredar

( Helmina dan Hidayat, 2017)

(Helmina dan Hidayat, 2017)

$$
\text { Kepemilikan Manajerial }\left(\mathrm{X}_{2}\right)
$$

Kepemilikan manajerial diperoleh dari jumlah saham yang dimiliki oleh direksi dan manajer dibagi dengan jumlah saham yang beredar. (Ismiati 2017)

$$
\text { Ukuran Perusahaan }\left(\mathrm{X}_{3}\right)
$$

Skala besar kecilnya perusahaan yang ditentukan oleh beberapa hal antara lain adalah total penjualan, total aktiva, dan rata-rata tingkat penjualan perusahaan.

Helmina dan Hidayat (2017)

$$
\text { Kebijakan Dividen (Y) }
$$

Kebijakan dividen diproksikan dengan dividend payout ratio. Dividend payout ratio menunjukkan presentase dari setiap dollar yang dihasilkan oleh sebuah perusahaan yang didistribusikan kepada pemilik dalam bentuk tunai. Dividend payout ratio dihitung dengan membagi dividend kas per saham dengan laba per saham.

Gitman dan Zutter (2012:577)
- Total Asset

- Jumlah saham yang dimiliki oleh manajerial

- Jumlah saham yang beredar.

Size $=$ Ln total asset

Rasio

Helmina dan Hidayat (2017)

- Dividend per share (dividen per saham).

- Earning per share (laba per saham).
$\mathrm{DPR}=\frac{\text { Devidend Per Share }}{\text { Earning Per Share }} \times 100 \%$

Rasio

\begin{tabular}{|c|c|c|c|c|}
\hline \multicolumn{5}{|c|}{ Dependent Variable: DPR } \\
\hline \multicolumn{5}{|c|}{ Method: Panel Least Squares } \\
\hline \multicolumn{5}{|c|}{ Date: 09/26/18 Time: 21:07 } \\
\hline \multicolumn{5}{|c|}{ Sample: 20082017} \\
\hline \multicolumn{5}{|c|}{ Periods included: 10} \\
\hline \multicolumn{5}{|c|}{ Cross-sections included: 6} \\
\hline \multicolumn{5}{|c|}{ Total panel (balanced) observations: 60} \\
\hline Variable & Coefficient & Std. Error & t-Statistic & Prob. \\
\hline $\mathrm{C}$ & 51.13539 & 43.53050 & 3.476963 & 0.0010 \\
\hline INST & 1.038502 & 0.185159 & 5.608703 & 0.0000 \\
\hline MOWN & -39.01389 & 0.914296 & -4.267095 & 0.0001 \\
\hline SIZE & 8.590680 & 2.216866 & 3.875145 & 0.0003 \\
\hline
\end{tabular}

Gitman dan Zutter (2012:577)
Tabel 2. Analisis Regresi Data Panel

Sumber: Hasil Olah Data Eviews 9
Tabel 3. Pengujian Hipotesis Common Effect

\begin{tabular}{llll}
\hline R-squared & 0.396222 & Mean dependent var & 54.00534 \\
Adjusted R-squared & 0.363877 & S.D. dependent var & 22.78646 \\
S.E. of regression & 18.17387 & Akaike info criterion & 8.702187 \\
Sum squared resid & 18496.22 & Schwarz criterion & 8.841810 \\
Log likelihood & -257.0656 & Hannan-Quinn criter. & 8.756802 \\
F-statistic & 12.24979 & Durbin-Watson stat & 0.648354 \\
Prob(F-statistic) & 0.000003 & & \\
\hline
\end{tabular}

Sumber: Hasil Olah Data Eviews 9

Tabel 4. Pengujian Hipotesis Common Effect

\begin{tabular}{lrrrr}
\hline Variable & Coefficient & Std. Error & t-Statistic & Prob. \\
\hline C & 51.13539 & 43.53050 & 3.476963 & 0.0010 \\
INST & 1.038502 & 0.185159 & 5.608703 & 0.0000 \\
MOWN & -39.01389 & 0.914296 & -4.267095 & 0.0001 \\
SIZE & 8.590680 & 2.216866 & 3.875145 & 0.0003 \\
\hline
\end{tabular}

Sumber: Hasil Olah Data Eviews 9 
Tabel 5. Koefisien Determinasi Simultan

\begin{tabular}{llll}
\hline R-squared & 0.396222 & Mean dependent var & 54.00534 \\
Adjusted R-squared & 0.363877 & S.D. dependent var & 22.78646 \\
S.E. of regression & 18.17387 & Akaike info criterion & 8.702187 \\
Sum squared resid & 18496.22 & Schwarz criterion & 8.841810 \\
Log likelihood & -257.0656 & Hannan-Quinn criter. & 8.756802 \\
F-statistic & 12.24979 & Durbin-Watson stat & 0.648354 \\
Prob(F-statistic) & 0.000003 & & \\
\hline
\end{tabular}

Sumber: Hasil Olah Data Eviews 9

Tabel 6. Koefisien Determinasi Parsial

\begin{tabular}{|c|c|c|c|c|c|c|c|c|}
\hline \multirow{3}{*}{ Model } & \multicolumn{5}{|c|}{ Coefficients $^{\mathrm{a}}$} & \multirow{2}{*}{\multicolumn{3}{|c|}{ Correlations }} \\
\hline & \multicolumn{2}{|c|}{$\begin{array}{l}\text { Unstandardized } \\
\text { Coefficients }\end{array}$} & \multirow{2}{*}{$\begin{array}{c}\begin{array}{c}\text { Stand- } \\
\text { ardized } \\
\text { Coeffi- } \\
\text { cients }\end{array} \\
\text { Beta }\end{array}$} & \multirow{2}{*}{$t$} & \multirow{2}{*}{ Sig. } & & & \\
\hline & B & $\begin{array}{l}\text { S td } \\
\text { Error }\end{array}$ & & & & $\begin{array}{l}\text { Zero- } \\
\text { order }\end{array}$ & $\begin{array}{c}\text { Par- } \\
\text { tial }\end{array}$ & Part \\
\hline $\begin{array}{l}\text { (Con- } \\
\text { stant) }\end{array}$ & $-21,358$ & 21,402 & &,- 998 & ,423 & & & \\
\hline $1 \mathrm{KI}$ & 1,261 &, 849 & 601 & 1,485 & ,276 & ,484 & ,724 & ,712 \\
\hline KM & $-32,750$ & 31,802 &,- 635 & $-1,030$ &, 411 &,- 158 &,- 589 &,- 494 \\
\hline UP & 11,281 & 10,774 &, 715 & 1,047 & ,405 & ,006 &, 595 &, 502 \\
\hline
\end{tabular}

a. Dependent Variable: DPR

Sumber: Hasil Olah data SPSS

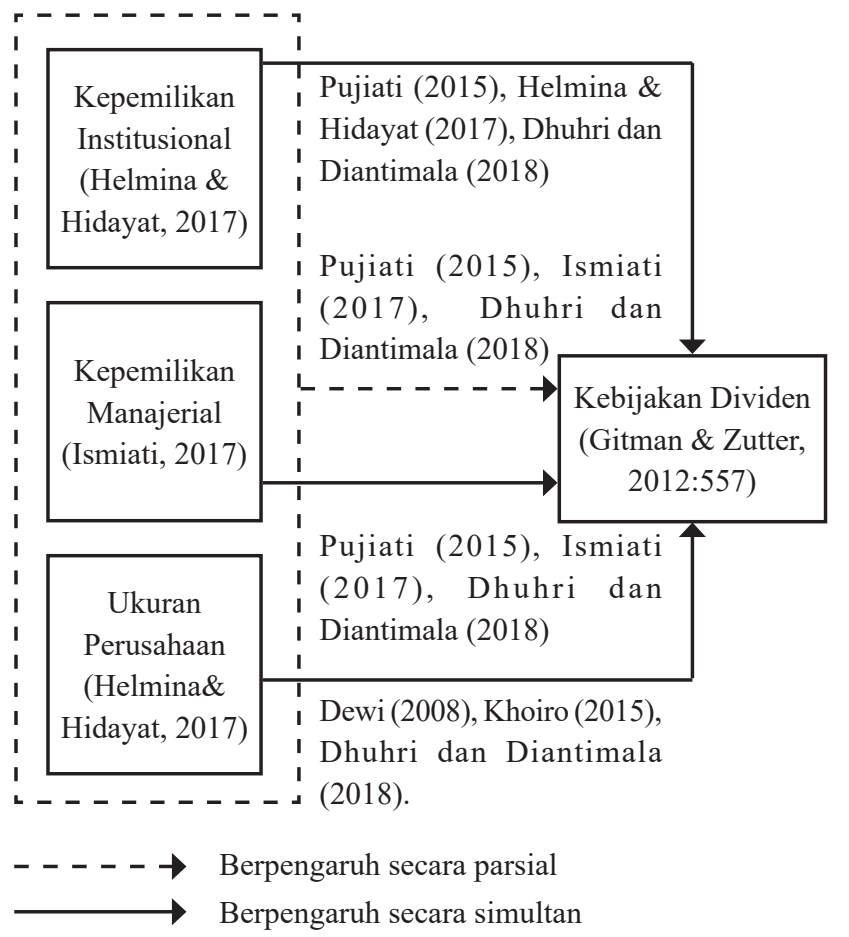

Gambar 1. Paradigma Penelitian

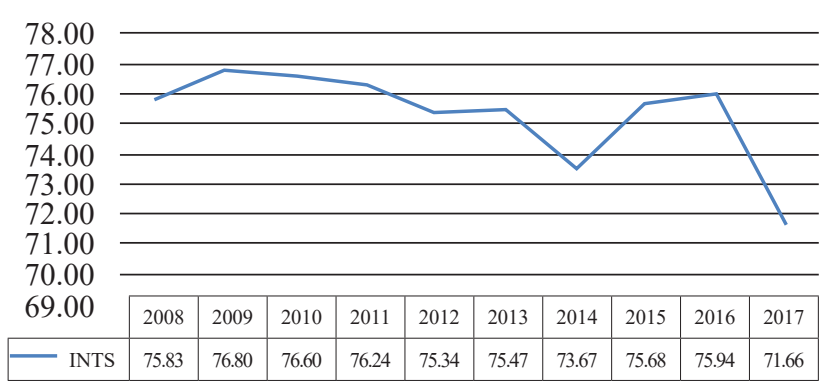

Sumber : www.idx.co.id (Data diolah)

Gambar 2. Rata-rata Kepemilikan Institusional Pada Perusahaan Manufaktur Sektor Industri Barang Konsumsi Yang Terdaftar Di Bursa Efek Indonesia Pada Periode 2008-2017

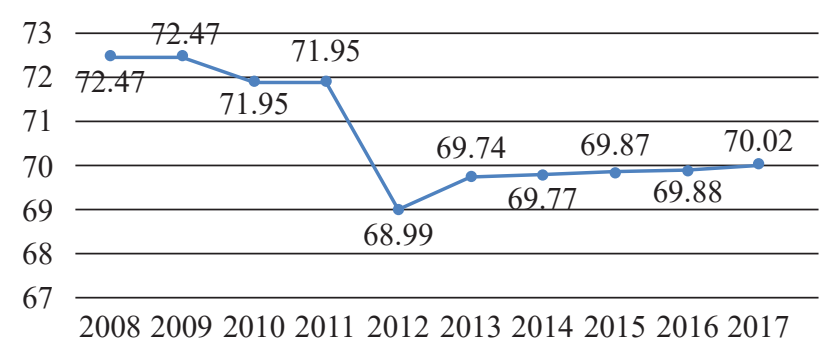

Sumber : www.idx.co.id (Data diolah)

Gambar 3. Rata-rata Kepemilikan Manajerial Perusahaan Manufaktur Sektor Industri Barang Konsumsi Periode 2008-2017

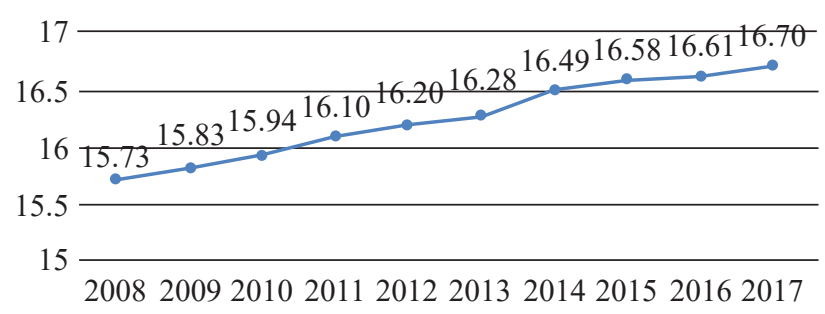

Sumber : www.idx.co.id (Data diolah)

Gambar 4. Rata-rata Ukuran Perusahaan Perusahaan Manufaktur Sektor Industri Barang Konsumsi Periode 2008-2017

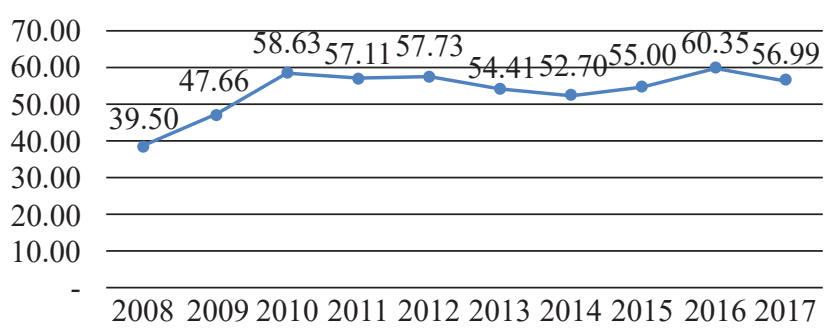

Sumber : www.idx.co.id (Data diolah)

Gambar 5. Rata-rata Kebijakan Dividen Perusahaan Manufaktur Sektor Industri Barang Konsumsi Periode 2008-2017 